\title{
A Review of Ethical Leadership and Other Ethics- Related Leadership Theories
}

\author{
Israr Ahmad (PhD student) \\ Yongqiang Gao (Professor) \\ School of Management, \\ Huazhong University of Science and Technology, Wuhan, P.R.China \\ Shafei Moiz Hali (Assistant Professor) \\ Department of Government and Public Policy, \\ National Defence University, Islamabad, Pakistan
}

Doi: 10.19044/esj.2017.v13n29p10 URL:http://dx.doi.org/10.19044/esj.2017.v13n29p10

\begin{abstract}
The role of ethics in leadership studies is very important for organizations. Leadership without ethics and integrity can be harmful both for the organizational stakeholders and society. The high-profiled scandals and the leadership involvement in unethical activities caused increase attention of the scholars and mainstream media in the leadership ethics (Hartog, 2015). This resulted a growing research in the field of ethical leadership behavior. For this reason, the present study review ethics-related leadership including ethical leadership and other ethic-related leadership theories to better understand the importance of the ethics and morality in these leadership constructs. This study also presented a comprehensive review on ethical leadership and its similarities and differences with other related leadership styles. Another focus of this study was to present the definitions of each leadership style and their scales, and to establish that how ethical leadership is distinct from each leadership style. Future directions and conclusion are presented in the last of the paper.
\end{abstract}

Keywords: Leadership, Ethical Leadership, Ethics-related Leadership theories, Scales, Ethics

\section{Introduction}

Whenever the issues related to ethic comes into discussion, the ethical behavior of leaders always takes a foremost attention from scholars and practitioners. According to Ciulla (1998), ethics and integrity is heart of the leadership, and should be taken seriously for success of the business and long-term survival of the organization. Ethical behavior of the leaders gets a 
thoughtful attention across the board after the highly publicized leadership scandals in businesses, and more specifically, the collapses of high profiled organization including leading financial institutions (Treviño, Nieuwenboer, \& Kish-Gephart, 2014), that caused the great recession worldwide in the recent past. Although, the recent interest from the researchers and academia in leadership ethics in mostly because of these recent unethical events (Hartog, 2015), however, leadership ethics has been discussed since long in different leadership theories (Zhu, Zheng, Riggio, \& Zhang, 2015).

Though, ethics and morality of leadership has been long discussed in normative terms in philosophical work (Ciulla, 1998), but the recent descriptive work in the social scientific terms from scholars inspired more research in the field of leadership ethics (Brown, Treviño, \& Harrison, 2005; Karianne Kalshoven, Den Hartog, \& De Hoogh, 2011). Despite the fact that every positive leadership style though discuss ethics and integrity as a component of leadership style and considered it important for effective leadership (Brown \& Mitchell, 2010; Hartog, 2015), but the effectiveness of these leadership styles always got some criticisms from scholars. The objective of the current review is to discuss the ethical aspect of different positive leadership styles as well the critique. Further, this paper aims to put forward the different measures used to assess these leadership styles. We also presented the comprehensive review on the ethics-based leadership constructs. Furthermore, this review discussed the similarities and likewise the differences of these leadership styles with ethical leadership as well as the different instruments developed for these ethics-related leadership. The focus of this review is purely on organizational and workplace psychological viewpoints rather than political, therefore this point should be kept in mind. This review has been organized as such that first, it discusses the ethical leadership concept and constructs developed for ethical leadership. Next, this paper gives a review of the other ethics-related leadership construct in details, and so the similarities and differences of these leadership styles with ethical leadership. Lastly, this study also discoursed the future direction for the research, and give a brief conclusion of the study.

\section{Overview of Ethical Leadership}

Ethical leadership caught enormous interest from the researchers, and thus been widely studied. The increased attention and heightened interest in the ethical leadership development is argued to be because of recent highprofile scandals (Brown et al., 2005; Hartog, 2015). Initial descriptive work on the ethical leadership was done by Trevino and colleagues through a series of studies to identity that what characteristics should ethical leaders possess and who should be called ethical leader (Treviño, Brown, \& Hartman, 2003; Treviño, Hartman, \& Brown, 2000). Following these studies, 
Brown et al. (2005) for first time conceptualize ethical leadership and linked ethical leadership with number of positive employee and organizational outcomes. The growing research across different cultures shown that ethical leadership can be effective to motivate employees, and is positively linked with favorable employees' outcomes including different attitudes and behavior, and found effective in diminution the undesirable outcomes including deviance and turnover intention (Bedi, Alpaslan, \& Green, 2016; Chen \& Hou, 2016; Chughtai, Byrne, \& Flood, 2015; Demirtas \& Akdogan, 2015; Ng \& Feldman, 2015). In the following part, we presented different definitions of ethical leadership and characteristics that ethical leader possess, and also the measures used for the ethical leadership.

\section{Definitions and Characteristics of Ethical Leadership}

For first time Brown and colleagues give the conceptualization to ethical leadership by using social learning and social exchange perspectives and defined it as "the demonstration of normatively appropriate conduct through personal actions and interpersonal relationships, and the promotion of such conduct to the followers through two-way communication, reinforcement, and decision-making" (Brown et al., 2005, p.120). They argued that under the supervision of ethical leader the followers imitate their leader behavior and believed to have a significant influence on follower ethical conduct and behaviors (Mayer, Aquino, Greenbaum, \& Kuenzi, 2012; Treviño et al., 2003).

According to Trevino and colleagues, ethical leadership must include the characteristics of both the "moral person" and "moral manager" (Brown \& Treviño, 2006; Treviño et al., 2000). Moral person facet of ethical leadership discusses the traits and/or character of the leader. Ethical leaders personify certain traits such as honesty, integrity, truthfulness, openness to input, respect and principled in decision making, and concerns for others (Trevino et al., 2000). While moral manager aspect of ethical leadership behavior deals with how leaders use their managerial power and leadership position to encourage and promote ethical standards and ethical behaviors in the workplace. Ethical leaders must be both strong moral manager and moral person (Brown \& Mitchell, 2010). In other words, morality must be an important part of the ethical leader self-concept as well as the guiding principle for the leaders every course of actions (Giessner, Van Quaquebeke, van Gils, van Knippenberg, \& Kollée, 2015).

Others also defined ethical leadership but differently, with pointing out the limitations of Brown and colleagues' definition. For example, De Hoogh and Den Hartog (2009) defined ethical leadership as the process in which a leader influences group activities to the organizational goals attainment in a socially responsible way. More specifically, this definition 
consider that a leader is ethical who is moral and caring, and their actions should be beneficial for all stakeholders including followers, organization and society (Hartog, 2015). Similarly, according to Gini (1997), a leader would be considered ethical whose do not intent to harm others and always respects all the affected parties rights. Likewise, Kanungo (2001) argued that the ethical leader must engage in the righteous acts and avoid harmful acts to others, and their actions must be based on altruistic motives rather than on self-centered. In these definitions, they take ethical leadership more in general term in which they considered the intentions and purpose of the leadership behavior rather than normatively appropriateness.

\section{Measures of Ethical Leadership}

There are several scales developed to measure ethical leadership behavior. The most widely used one was developed by Brown et al. (2005) called ethical leadership scale (ELS). To measure ethical leadership, Brown and colleagues by taking the conceptualization into descriptive perspective, developed ten-items ELS to measure ethical leadership. In addition to this, other scholars developed different scales of ethical leadership according to their conceptualization. For example, Yukl, Mahsud, Hassan, and Prussia (2013) developed a fifteen-items scale. Similarly, a multidimensional leadership scale was developed by including seven dimensions on their scale (Karianne Kalshoven et al., 2011). Karianne Kalshoven et al. (2011) Scale was named as ethical leadership work questionnaire (ELW). ELW included the dimensions such as ethical guidance, fairness, leader integrity, caring behavior, power sharing, role clarification, and concern for the sustainability. There were some other scales developed too but less tested and used (De Hoogh \& Den Hartog, 2008; Resick, Hanges, Dickson, \& Mitchelson, 2006).

Though extensively studies but these scales got some criticisms that need to be noted. Like, in ELS the two dimensions of ethical leadership "moral person and moral manager" was collapsed into one in the scale. Another important aspect that should be noted that some significant traits that associated with ethics are missing in this scale, such as integrity, and honesty (Zhu et al., 2015). Likewise, ELW mostly measures the moral manager dimension of the ethical leadership, and only few items were included related to personal characteristics aspects of leadership. Even some scholars argue that this scale lack solid theoretical foundation (e.g., Zhu et al., 2015). Thus, future research, by considering these shortcomings, should develop a further valid scale to measure ethical leadership.

\section{Other Ethics-related Leadership Styles}

Most of the positive leadership theories discussed the ethical and moral aspect of leader as a part of the leadership construct. In this portion of 
the paper, we presented those leadership styles one by one briefly, and also pointed out the similarities and differences of these similar leadership styles with the ethical leadership construct.

\section{Transformational Leadership}

Transformational leadership is noted a leadership style which share more commonalities, and closely aligned with ethical leadership (Brown \& Treviño, 2006). Moral and ethical component to the leadership was first introduced in transformational leadership theory (Burns, 1978), and played important role in the original conceptualization of transformational leadership (K. Kalshoven, 2010). Transformational leadership focus on communicating an inspiring and idealized vision of collective goals for the organization future to the followers (Bass \& Riggio, 2006). One of the important and necessary element of transformational leadership is believed to be the charismatic aspect which composed of charisma and inspirational motivation dimension (Bass \& Riggio, 2006). Transformational leadership overlaps on some aspects with the ethical leadership such as concerns for others, role modeling aspects, and consistency in leader's act with internal values (Brown \& Treviño, 2006). Moreover, as charisma is part of transformational leadership theory that's why the transformational leadership has much in common with charismatic leadership too (Bass \& Riggio, 2006). Ethical conduct and morality is an essential part of both transformational and charismatic leadership. But scholars argued that transformational and charismatic leadership can be both good as well bad to the followers, and/or can take both the ethical and unethical forms, depends upon their motivation (Bass \& Steidlmeier, 1999; House \& Howell, 1992). Both leadership styles have traits that can possibly employed for self-serving drives, to manipulate and deceive others, and can be used for the others exploitation (Bass, 1990; K. Kalshoven, 2010; Pinnington, 2011; Price, 2003). Researchers differentiate between the sub-types of these leadership styles. Such as, Bass and Steidlmeier (1999) differentiate transformational leadership into two sub-types, pseudo-transformational and authentic transformational leadership. Pseudo-transformational leader use authority for self-interest, lack morality, and power-oriented. While authentic transformational leader is genuine, ethical and use authority for the good of others and community. Similarly, House and Howell (1992) made a distinction between socialized and personalized charismatic leadership, by arguing that the socialized charismatic leaders are ethical, have concerns for moral use of power and such leader use the authority power for the well-being of others. While personalized charismatic leaders use the authority for their own interest and have low concern for the ethical use of the authority. Even after these distinctions in the leadership sub-types, scholars have still some concerns 
about it. For example, scholars have argued that it is difficult for employees to distinguish between pseudo-transformational and authentic leaders as they show similar behaviors, and the manipulative behaviors of pseudotransformational leaders may make it hard for the followers to recognize between both sub-types (Dasborough \& Ashkanasy, 2002; Hartog, 2015). However, ethical leadership differs from these constructs in numbers of aspects. For example, morality, ethical behavior, and fairness are the central drivers in ethical leadership to influence and motivates others, but these are not the key aspects of the transformational leadership (Hartog, 2015). Further, ethical leaders emphasize more on transactional modes of influences than transformational leadership, such as rewards for proper behaviors and punishment for improper acts. Similarly, transformational leadership is more visionary and future-oriented, and such leaders motivates employees intellectually, while ethical leadership do not revolve around such purposes (Brown \& Treviño, 2006).

\section{Scale of Transformational Leadership}

The scale for transformational leadership was developed by Bass and Avolio (1997) called Multifactor Leadership Questionnaire (MLQ), is the mostly used scale to date. This scale is further revised and currently contained 20 items measuring five dimensions of transformational leadership that included the inspirational motivation, idealized influence, individualized consideration, and intellectual stimulation (Avolio, Bass, \& Jung, 1999). The idealized influence dimension of this scale measures the ethical aspect of the leadership, but it does not cover the full domain of the ethical leadership.

\section{Spiritual Leadership}

Also, ethical leadership share some similarities with, but differs from spiritual leadership (Brown \& Treviño, 2006). According to Fry (2003), spiritual leadership included "the values, attitudes, and behaviors that are necessary to intrinsically motivate one's self and others so that they have a sense of spiritual survival through calling and membership" (p-711). Spiritual leadership style includes the aspects of ethics, religion-focused and values-based approaches, and such leaders are ethical, compassionate, and treat others with respect (Brown \& Treviño, 2006; Reave, 2005). But spiritual leadership incorporates numbers of features which is not associated with ethical leadership. Like, spiritual leaders are visionary, have more focus on religion and calling to serve higher purpose. Moreover, opposite to spiritual leadership, ethical leadership operates the transactional mechanisms. 


\section{Measure of Spiritual Leadership}

Spiritual leadership scale was developed by Fry, Vitucci, and Cedillo (2005). This scale was developed by taking five dimensions to measure spiritual leadership. Five dimensions were altruistic love, faith, vision, meaning, and membership. The altruistic love dimension in this scale is similar to the moral person aspect of ethical leadership (Zhu et al., 2015). The altruistic love dimension was measured with seven items. Thus, spiritual leadership also discuss the ethical aspect of leadership.

\section{Authentic Leadership}

Authentic leadership has been defined by Walumbwa, Avolio, Gardner, Wernsing, and Peterson (2008) as "a pattern of leader behavior that draws upon and promotes both positive psychological capacities and a positive ethical climate, to foster greater self-awareness, an internalized moral perspective, balanced processing of information, and relational transparency on the part of leaders working with followers, fostering positive self-development" (p.94). Authentic leaders have the core characteristics of openness, self-awareness, transparency, concern for others and consistency, and such leader have positive attributes of confidence, optimistic, resilient, and hope (Luthans \& Avolio, 2003). According to Brown and Treviño (2006), ethical leadership and authentic leadership share similarity such as social motivation and people orientation, and also, both are ethically principled leaders. But, some key attributes that are part of authentic leadership such as the self-awareness and authenticity, which is not emphasized in the ethical leadership.

\section{Measure of Authentic Leadership}

Authentic Leadership Scale (ALS) was developed by Walumbwa et al. (2008) based on above definition to measure the authentic leadership behavior. This scale of ALS was consisting of four dimensions. (1) Selfawareness dimension was measured with four-item, (2) relational transparency with five-item, (3) balance processing of information with three-item, and (4) internalized moral perspective with five-item, thus making a full scale of 16 items. The internalized moral perspective of authentic leadership is characterized of high ethical standard and values, and such leader consider the ethical consequences of their decisions.

\section{Servant Leadership}

Servant leadership theory also considered the moral aspect of the leadership (Graham, 1991; Greenleaf, 1977). Although, there is no overall consensus about the exact behavior of the servant leader, but most of the studies followed the definition of Greenleaf (1977), that defined servant 
leadership as the one who emphases on empowering and development of followers, while at the same time inspires the followers to act as servant leaders too (Newman, Schwarz, Cooper, \& Sendjaya, 2015). Ehrhart (2004) highlighted seven main characteristics of servant leadership: putting followers first, support followers to develop and success, build relations with followers, empowered them, having conceptual skills, behave ethically, and create value for the community. The unique perspective of servant leadership theory is that leaders gives preference to followers over the organization. Ethical leadership and servant leadership both emphasis on strong ethical perspective, which is a common sharing perspective in both leadership styles. Moreover, both leadership styles emphases on follower empowerment, relationship building and followers development. However, the two leadership theories are also differing in some respect. For example, servant leader places the followers interest before and above from all other stakeholders including organization, while ethical leader emphasis to have great impact on the both followers and organization.

\section{Instruments for Servant Leadership}

Numerous scales have been developed to measure servant leadership. For example, based on Spears (1998) works, Ehrhart (2004) developed 14items scale based on seven dimensions of servant leadership. Similarly, Barbuto Jr and Wheeler (2006), developed another scale based on Spears (1998) 10 characteristic of servant leadership work, and reduced this scale to five dimensions based on factor analysis. Likewise, another scale developed by Liden, Wayne, Zhao, and Henderson (2008). This scale developed by these scholars was based on seven dimensions with total items of 28 . These all scales included the important dimension of ethic and to assess the ethical aspect of leadership, such as, Liden et al. (2008) scale measured the "behaving ethically" dimension, while Barbuto Jr and Wheeler (2006) scale measured the altruistic calling dimension.

\section{Paternalistic Leadership}

Paternalistic leadership, which is mostly studied in the non-Western cultures such as China, Turkey, India, Japan and Mexico, is another leadership construct that discuss moral aspect of the leadership. Paternalistic leadership construct composed of three dimensions; authoritarianism, benevolence, and morality (Chen, Eberly, Chiang, Farh, \& Cheng, 2014). Moral element is the shared aspect in both leadership styles. But the authoritarianism characteristic of paternalistic leadership emphasizes on centralized decision-making and one-way communication, while contrary to this, ethical leaders highlights the two-way communication and share power 
with subordinates (Chen et al., 2014; Hartog, 2015), thus, make ethical leadership distinct from paternalistic leadership too.

\section{Scale of Paternalistic Leadership}

Paternalistic leadership is not a unified construct (Chen et al., 2014) and thus, consist of three dimensions as I mentioned above. Each dimension is consisting of 10 items, thus make the total into 30 in this scale. This scale was developed by Chen et al. (2014) based on Cheng, Chou, Huang, Farh, and Peng (2003) initial scale. Morality is the basic dimension for this scale of paternalistic leadership which was measured with 10 items.

\section{Discussion and Conclusion}

Numerous positive leadership theories discuss the ethics and morality of the leadership. However, ethical leadership has been widely accepted a leadership style that discuss and cover the entire domain of ethical behavior of the leadership. Apart from ethical leadership, several other leadership theories also considered the ethical aspect of leadership, but these ethicsrelated leadership styles do not cover the complete domain of the ethical leader. Although, the above-mentioned distinctions clarify that how ethical leadership is conceptually different from other related similar constructs, however, some empirical studies reported high correlation with related constructs (Barling, Christie, \& Turner, 2008; Karianne Kalshoven et al., 2011; Mayer et al., 2012; Ofori, 2009). These research studies have shown that ethical leadership is empirically related to some of the similar related constructs such as transformational, servant, and authentic leadership, but argued that it is well distinct from these constructs.

\section{Future Research Directions}

As we discussed that these leadership theories discuss the ethical aspect of leadership but most of these theories are in early stage of development, and thus require more clear understanding. Furthermore, studies reported a high correlation between the various scale and similarly scholars pointed out overlapping between these styles too. Therefore, it may possible that the followers may not be able to make distinctions between these different leadership styles clearly. Thus, future research need to clarify this point too. Moreover, it is also not clear that ethical leadership behavior is a stable behavior or not, such that leader can be ethical publicly but involve in unethical acts privately (Zhu et al., 2015). Thus, researcher need to investigate this aspect of the ethical leadership in future research.

To date most of the research work on ethical leadership is mostly cross-sectional in nature. To be clearer about that how ethical leadership unfolds with passing time and to know about the direction of causality, a 
further need of other methodological research should be consider. It can be done with experimental work design and/or longitudinal research design. Another problem in the methodology is that, most of the time the data about leadership behavior including ethical leadership was collected from the followers. Thus, studies rely on the perceived leadership behavior, which can be biased. Hence, the experimental or longitudinal study design may accommodate these issues too. Furthermore, while discussing instruments for each leadership styles, it was observed that there is no consensus on one definition or scale. This issue can question the universality of each leadership construct. Thus, future research needs to provide a more comprehensive and valid leadership definition and scales. Also, there is still a very limited work on cross-cultural differences, that need to be explored.

\section{References:}

1. Avolio, B. J., Bass, B. M., \& Jung, D. I. (1999). Re $\square$ examining the components of transformational and transactional leadership using the Multifactor Leadership. Journal of occupational and organizational psychology, 72(4), 441-462.

2. Barbuto Jr, J. E., \& Wheeler, D. W. (2006). Scale development and construct clarification of servant leadership. Group \& Organization Management, 31(3), 300-326.

3. Barling, J., Christie, A., \& Turner, N. (2008). Pseudotransformational leadership: Towards the development and test of a model. Journal of Business Ethics, 81(4), 851-861.

4. Bass, B. M. (1990). From transactional to transformational leadership: Learning to share the vision. Organizational dynamics, 18(3), 19-31.

5. Bass, B. M., \& Avolio, B. J. (1997). Full range leadership development: Manual for the Multifactor Leadership Questionnaire: Mind Garden Palo Alto, CA.

6. Bass, B. M., \& Riggio, R. E. (2006). Transformational leadership: Psychology Press.

7. Bass, B. M., \& Steidlmeier, P. (1999). Ethics, character, and authentic transformational leadership behavior. The Leadership Quarterly, 10(2), 181-217.

8. Bedi, A., Alpaslan, C. M., \& Green, S. (2016). A Meta-analytic Review of Ethical Leadership Outcomes and Moderators. Journal of Business Ethics, 139(3), 517-536. doi:10.1007/s10551-015-2625-1

9. Brown, M. E., \& Mitchell, M. S. (2010). Ethical and Unethical Leadership: Exploring New Avenues for Future Research. Business Ethics Quarterly, 20(4), 583-616. 
10. Brown, M. E., \& Treviño, L. K. (2006). Ethical leadership: A review and future directions. The Leadership Quarterly, 17(6), 595-616.

11. Brown, M. E., Treviño, L. K., \& Harrison, D. A. (2005). Ethical leadership: A social learning perspective for construct development and testing. Organizational Behavior and Human Decision Processes, 97(2), 117-134.

12. Burns, J. M. (1978). Leadership New York. NY: Harper and Row Publishers.

13. Chen, A. S.-Y., \& Hou, Y.-H. (2016). The effects of ethical leadership, voice behavior and climates for innovation on creativity: A moderated mediation examination. The Leadership Quarterly, 27(1), 1-13.

14. Chen, X.-P., Eberly, M. B., Chiang, T.-J., Farh, J.-L., \& Cheng, B.-S. (2014). Affective trust in Chinese leaders: Linking paternalistic leadership to employee performance. Journal of management, 40(3), 796-819.

15. Cheng, B., Chou, L., Huang, M., Farh, J.-L., \& Peng, S. (2003). A triad model of paternalistic leadership: Evidence from business organizations in Mainland China. Indigenous Psychological Research in Chinese Societies.

16. Chughtai, A., Byrne, M., \& Flood, B. (2015). Linking ethical leadership to employee well-being: The role of trust in supervisor. Journal of Business Ethics, 128(3), 653-663.

17. Ciulla, J. B. (1998). Ethics, the Heart of Leadership. Westport, CT: Quorum Books.

18. Dasborough, M. T., \& Ashkanasy, N. M. (2002). Emotion and attribution of intentionality in leader-member relationships. The Leadership Quarterly, 13(5), 615-634.

19. De Hoogh, A., \& Den Hartog, D. (2009). Ethical leadership: the positive and responsible use of power In Power and Interdependence in Organizations, ed. D Tjosvold, B Wisse, pp. 338-54. Cambridge, UK: Cambridge Univ. Press.

20. De Hoogh, A. H. B., \& Den Hartog, D. N. (2008). Ethical and despotic leadership, relationships with leader's social responsibility, top management team effectiveness and subordinates' optimism: A multi-method study. The Leadership Quarterly, 19(3), 297-311.

21. Demirtas, O., \& Akdogan, A. A. (2015). The effect of ethical leadership behavior on ethical climate, turnover intention, and affective commitment. Journal of Business Ethics, 130(1), 59-67.

22. Ehrhart, M. G. (2004). Leadership and procedural justice climate as antecedents of unit $\square$ level organizational citizenship behavior. Personnel Psychology, 57(1), 61-94. 
23. Fry, L. W. (2003). Toward a theory of spiritual leadership. The Leadership Quarterly, 14(6), 693-727.

24. Fry, L. W., Vitucci, S., \& Cedillo, M. (2005). Spiritual leadership and army transformation: Theory, measurement, and establishing a baseline. The Leadership Quarterly, 16(5), 835-862.

25. Giessner, S. R., Van Quaquebeke, N., van Gils, S., van Knippenberg, D., \& Kollée, J. A. J. M. (2015). In the moral eye of the beholder: the interactive effects of leader and follower moral identity on perceptions of ethical leadership and LMX quality. Frontiers in Psychology, 6(1126).

26. Gini, A. (1997). Moral leadership and business ethics. Journal of Leadership Studies, 4(4), 64-81.

27. Graham, J. W. (1991). Servant-leadership in organizations: Inspirational and moral. The Leadership Quarterly, 2(2), 105-119.

28. Greenleaf, R. K. (1977). Servant leadership: New York: Paulist Press.

29. Hartog, D. N. D. (2015). Ethical Leadership. Annual Review of Organizational Psychology and Organizational Behavior, 2(1), 409434.

30. House, R. J., \& Howell, J. M. (1992). Personality and charismatic leadership. The Leadership Quarterly, 3(2), 81-108.

31. Kalshoven, K. (2010). Ethical leadership: through the eyes of employees. Unpublished doctoral dissertation.

32. Kalshoven, K., Den Hartog, D. N., \& De Hoogh, A. H. (2011). Ethical leadership at work questionnaire (ELW): Development and validation of a multidimensional measure. The Leadership Quarterly, 22(1), 51-69.

33. Kanungo, R. N. (2001). Ethical values of transactional and transformational leaders. Canadian Journal of Administrative Sciences/Revue Canadienne des Sciences de l'Administration, 18(4), 257-265.

34. Liden, R. C., Wayne, S. J., Zhao, H., \& Henderson, D. (2008). Servant leadership: Development of a multidimensional measure and multi-level assessment. The Leadership Quarterly, 19(2), 161-177.

35. Luthans, F., \& Avolio, B. (2003). Authentic Leadership: A Positive Development Approach (in:) KS Cameron, JE Dutton, RE Quinn (eds), Positive Organizational Scholarship: Berrett-Koehler, San Francisco.

36. Mayer, D. M., Aquino, K., Greenbaum, R. L., \& Kuenzi, M. (2012). Who displays ethical leadership, and why does it matter? An examination of antecedents and consequences of ethical leadership. Academy of Management Journal, 55(1), 151-171. 
37. Newman, A., Schwarz, G., Cooper, B., \& Sendjaya, S. (2015). How Servant Leadership Influences Organizational Citizenship Behavior: The Roles of LMX, Empowerment, and Proactive Personality. Journal of Business Ethics, 1-14.

38. Ng, T. W. H., \& Feldman, D. C. (2015). Ethical leadership: Metaanalytic evidence of criterion-related and incremental validity. Journal of applied psychology, 100(3), 948-965.

39. Ofori, G. (2009). Ethical leadership: Examining the relationships with full range leadership model, employee outcomes, and organizational culture. Journal of Business Ethics, 90(4), 533.

40. Pinnington, A. H. (2011). Leadership development: Applying the same leadership theories and development practices to different contexts? Leadership, 7(3), 335-365.

41. Price, T. L. (2003). The ethics of authentic transformational leadership. The Leadership Quarterly, 14(1), 67-81.

42. Reave, L. (2005). Spiritual values and practices related to leadership effectiveness. The Leadership Quarterly, 16(5), 655-687.

43. Resick, C. J., Hanges, P. J., Dickson, M. W., \& Mitchelson, J. K. (2006). A cross-cultural examination of the endorsement of ethical leadership. Journal of Business Ethics, 63(4), 345-359.

44. Spears, L. C. (1998). Tracing the growing impact of servant leadership. Insights on leadership: Service, stewardship, spirit, and servant-leadership, 1-12.

45. Treviño, L. K., Brown, M., \& Hartman, L. P. (2003). A Qualitative Investigation of Perceived Executive Ethical Leadership: Perceptions from Inside and Outside the Executive Suite. Human Relations, 56(1), 5-37.

46. Treviño, L. K., Hartman, L. P., \& Brown, M. (2000). Moral person and moral manager: How executives develop a reputation for ethical leadership. California management review, 42(4), 128-142.

47. Treviño, L. K., Nieuwenboer, N. A. d., \& Kish-Gephart, J. J. (2014). (Un)Ethical Behavior in Organizations. Annual Review of Psychology, 65(1), 635-660.

48. Walumbwa, F. O., Avolio, B. J., Gardner, W. L., Wernsing, T. S., \& Peterson, S. J. (2008). Authentic leadership: Development and validation of a theory-based measure. Journal of management, 34(1), 89-126.

49. Yukl, G., Mahsud, R., Hassan, S., \& Prussia, G. E. (2013). An Improved Measure of Ethical Leadership. Journal of Leadership \& Organizational Studies, 20(1), 38-48. 
50. Zhu, W., Zheng, X., Riggio, R. E., \& Zhang, X. (2015). A Critical Review of Theories and Measures of Ethics $\square$ Related Leadership. New directions for student leadership, 2015(146), 81-96. 